\title{
Potentiation of Bleomycin in Jurkat Cells by Fungal Pycnidione
}

\author{
Mayumi Kaneko, ${ }^{a, \#}$ Daisuke Matsuda, ${ }^{a, \#}$ Masaki Ohtawa, ${ }^{a}$ Takashi Fukuda, ${ }^{b}$ Tohru Nagamitsu, ${ }^{a}$ \\ Takao Yamori, ${ }^{c}$ and Hiroshi Tomoda*,a \\ ${ }^{a}$ Graduate School of Pharmaceutical Sciences, Kitasato University: ${ }^{b}$ Kitasato Institute for Life Sciences and Gradu- \\ ate School of Infection Control Sciences, Kitasato University; 5-9-1 Shirokane, Minato-ku, Tokyo 108-8641, Japan: \\ and ${ }^{c}$ Division of Molecular Pharmacology, Cancer Chemotherapy Center, Japanese Foundation for Cancer Research; \\ 3-8-31 Ariake, Koto-ku, Tokyo 170-8550, Japan.
}

Received June 13, 2011; accepted October 18, 2011; published online November 7, 2011

\begin{abstract}
Most cancer cells have mutations in genes at the G1 checkpoint and repair DNA only in the G2 phase; therefore, the G2 checkpoint is a potential target to develop novel therapy. In the course of screening, a known compound, pycnidione, was isolated from the fungal culture broth of Gloeotinia sp. FKI-3416. Pycnidione irreversibly abrogated bleomycin-induced G2 arrest in Jurkat cells and synergically potentiated the cytotoxicity of bleomycin. To elucidate the mechanism of action, the effect of pycnidione on the signal transduction of the G2 checkpoint was analyzed, showing that the increased phospho-cyclin dependent kinase-1 (CDK1) level caused by bleomycin was abrogated in the presence of pycnidione, indicating that cells did not arrest at the G2 phase. Moreover, under these conditions, Chk1 and Chk2 levels were markedly downregulated. Thus, we concluded that pycnidione abrogated bleomycin-induced G2 arrest by decreasing Chk1 and Chk2.
\end{abstract}

Key words pycnidione; G2 arrest; bleomycin

DNA damage induces signal transduction pathways known as checkpoints, which arrest cell cycle progression and permit DNA repair. ${ }^{1)}$ Checkpoints arrest cells in the G1 phase to prevent replication of damaged DNA, and in the G2 phase to prevent the segregation of damaged chromosomes during mitosis. Normal cells can repair DNA at G1 and G2 phases, whereas most cancer cells have mutations in genes involved in the G1 checkpoint, such as $p 53, p 16 T N K 4$ or $R b,{ }^{2)}$ and can repair DNA only in the G2 phase. Accordingly, disruption of the G2 checkpoint in cancer cells is expected to increase sensitivity to DNA-damaging reagents such as bleomycin, cisplatin and camptothecin, causing selective cell death of cancer cells by the accumulation of mutations in genes ${ }^{3)}$; therefore, the G2 checkpoint is a potential target for development of a novel therapy against intractable cancers.

At the G2 checkpoint, DNA damage activates the ataxia telangiectasia-mutated (ATM) and A-T and rad-3-related (ATR) members of the phosphoinositide kinase family, and induced the phosphorylation of histone H2A.X. ${ }^{4}$ A signal is then transmitted through the downstream protein kinases Chk1 and Chk2, ${ }^{4-6)}$ which are able to phosphorylate Cdc25C at Ser216. This phosphorylation is thought to directly prevent $\mathrm{Cdc} 25 \mathrm{C}$ from activating cyclic dependent kinase-1 (CDK1) kinase. ${ }^{8)}$ Chk1 and Chk2 can also phosphorylate and activate Wee1, a kinase that catalyzes CDK1 inhibitory phosphorylation. ${ }^{9,10}$ ) Several G2 checkpoint abrogators have been reported to date; for example, UCN-01, a derivative of staurosporin, abrogated DNA damage-induced S and G2 arrest due to inhibition of Chk1 and perhaps Chk2. ${ }^{11)}$ Although Phase I clinical trials of UCN-01 have been completed, UCN-01 was found to bind readily to human plasma proteins and to inhibit kinases other than Chk1 and Chk2, which may result in unexpected side effects in patients. ${ }^{12,13)}$ SB218078 ${ }^{14)}$ and Gö6979 ${ }^{15}$ were reported recently to specifically inhibit $\mathrm{Chk} 1$, and their binding activity to human plasma proteins was stronger than that of UCN-01. Caffeine and PD0166285 inhibit the checkpoint kinases ATM and ATR, ${ }^{16)}$ and Weel kinase, ${ }^{17)}$ respectively. Suganuma et al. previously reported that the short peptide corresponding to amino acids $211-221$ of human $\mathrm{Cdc} 25 \mathrm{C}$, which is an important phosphatase in the G2 checkpoint, fused with part of human immunodeficiency virus (HIV)-TAT, can efficiently disrupt the cell cycle G2 checkpoint, which is activated by DNA damage, and can thereby sensitize cancer cells but not normal cells to anticancer reagents. ${ }^{3)}$ On the basis of these findings, CBP501, ${ }^{18)}$ a superior analog, and AZD7762 ${ }^{19)}$ have been developed as G2 checkpoint abrogators in clinical trials.

Jurkat, a human T-cell leukemia-derived cell line, depends on the G2 checkpoint to repair DNA damage since it loses the G1 checkpoint by lacking functional p53. ${ }^{3}$ ) We established a cell-based assay using Jurkat cells to screen microbial culture broths for G2 checkpoint abrogators. ${ }^{20-22)}$ Bleomycin and colchicine were used to measure whether a culture broth (or sample) shows G2 checkpoint abrogation activity. Bleomycin, a DNA-damaging agent, arrests the cell cycle at the G2 phase of Jurkat cells, while microtubule-disrupting colchicine arrests at the $\mathrm{M}$ phase. Samples were selected that showed abrogation of bleomycin-induced G2 arrest but had no effect on colchicineinduced $\mathrm{M}$ phase arrest. During this screening program, pycnidione (Fig. 1A), a fungal metabolite previously reported to inhibit stromelysin, ${ }^{23)}$ cell growth, ${ }^{24)}$ and plasmodial activity, ${ }^{25}$ was found to abrogate G2 arrest. In this study, we describe the activity and the mechanism of action of pycnidione as a G2 arrest abrogator.

\section{MATERIALS AND METHODS}

Materials RPMI1640, bovine serum albumin (BSA), ATP, thiazolyl blue tetrazolium bromide (MTT), deuterochloroform, ellipticine, MG132, propidium iodide, ribonuclease A, colchicine, Triton X-100, and IGEPAL CA-630 were purchased from Sigma-Aldrich (St. Louis, MO, U.S.A.). Penicillin $\left(1.0 \times 10^{4}\right.$ units $\left./ \mathrm{mL}\right)$ and streptomycin $\left(1.0 \times 10^{4} \mathrm{mg} / \mathrm{mL}\right)$ solution were obtained from GIBCO (Grand Island, NY, U.S.A.). Fetal bovine serum (FBS) was from Hyclone (Logan, UT, U.S.A.). 
A<smiles>CC1=CC(=O)C(O)=CC1=O</smiles>

B

a)

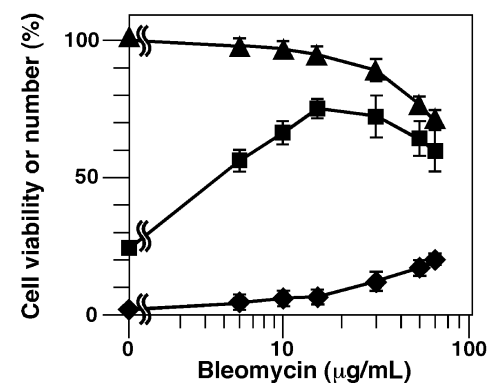

b)

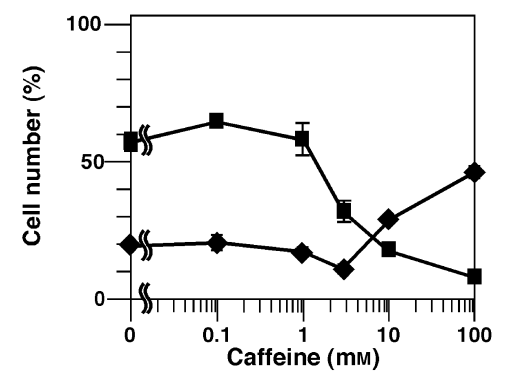

C

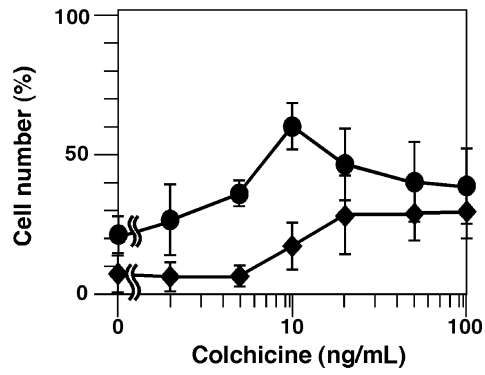

D

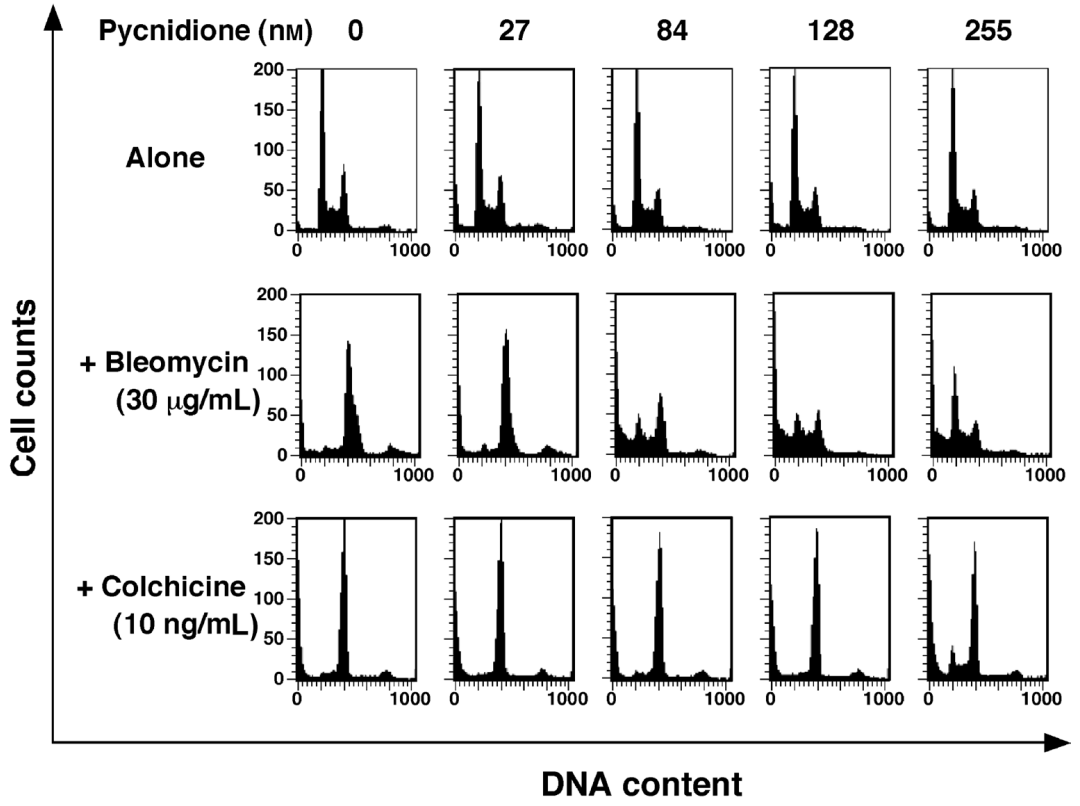

E

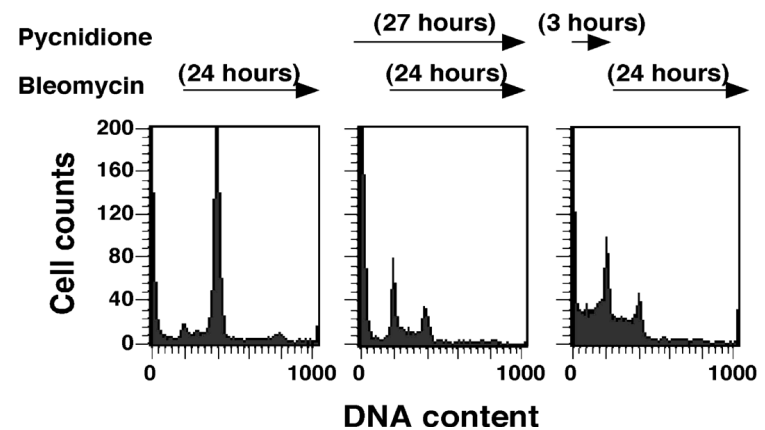

Fig. 1. Effect of Pycnidione on the Cell Cycle Status of Jurkat Cells Treated with Bleomycin and Colchicine

(A) Structure of pycnidione. (B,C) Jurkat cells $\left(5.0 \times 10^{5}\right.$ cells $\left./ \mathrm{mL}\right)$ were incubated in a 96-well plate with (B) bleomycin (a) and caffeine (b) or (C) colchicine at the indicated concentrations for $24 \mathrm{~h}$. After treatment, cell viability was evaluated by MTT assay $(\mathbf{\Delta})$ and the distribution in the cell cycle was analyzed by FACS (Sub G1: $\bullet$ G2: and M: E). Each value represents the mean \pm S.D. of 4 independent experiments. (D) Jurkat cells $\left(5.0 \times 10^{5}\right.$ cells $\left./ \mathrm{mL}\right)$ treated with pycnidione only or in combination with bleomycin or colchicine. The distribution in the cell cycle was analyzed by flow cytometry $24 \mathrm{~h}$ after incubation. (E) Jurkat cells $\left(5.0 \times 10^{5}\right.$ cells $\left./ \mathrm{mL}\right)$ were incubated with pycnidione $(255 \mathrm{~nm}$, middle and right panels) or methanol (left panel) for $3 \mathrm{~h}$. After removal of pycnidione (right panel), cells were incubated for $24 \mathrm{~h}$ in the presence of $30 \mu \mathrm{g} / \mathrm{mL}$ bleomycin (all panels). Then, DNA was stained with propidium iodide and the distribution in the cell cycle was analyzed by flow cytometry. 
Bleomycin (Nippon Kayaku, Tokyo, Japan) and Block Ace (a blocking agent made from milk; Yukijirushi Nyugyo, Tokyo, Japan) were also used.

${ }^{1} \mathrm{H}-\mathrm{NMR}(400 \mathrm{MHz})$ spectra were measured with a spectrometer (XL-400; Varian, Palo Alto, CA, U.S.A.) in deuterochloroform. The low-resolution mass spectra (LR-MS) were measured with LC/MS. LC/MS experiments were performed on the JMS-T100LP (JEOL, Tokyo, Japan) coupled with HPLC (column; Symmetry C18 (Waters, Milford, MA, U.S.A.), $2.1 \times 150 \mathrm{~mm}$; solvent, $50 \%$ acetonitrile in $0.050 \%$ formic acid; detection, $\mathrm{UV}$ at $210 \mathrm{~nm}$; flow rate, $0.20 \mathrm{~mL} / \mathrm{min}$ ).

Antibodies Mouse monoclonal anti-CDK1 p34 (17), antiChk2 (A-12), anti-Cdc25C (H-6), and anti-cyclin B1 (D-11) were purchased from Santa Cruz Biotechnology (Santa Cruz, CA, U.S.A.). Mouse monoclonal anti-Chk1 (clone 2G11D5), anti-CDK2 (clone AN4.3) and anti-cyclin A (clone BF863), and rabbit polyclonal anti-Weel were obtained from Millipore (Billerica, MA, U.S.A.). Mouse monoclonal anti-cyclin D3 (DCS22) and anti-CDK6 (DCS83), and rabbit polyclonal anti-phospho-CDK1 (Tyr15) and anti-phospho-Histone H2A.X (Ser139) were from Cell Signaling Technology (Beverly, MA, U.S.A.). Anti-actin (clone C4; CHEMICON International, Temecula, CA, U.S.A.) was also used. Rabbit polyclonal antimouse immunoglobulin (Ig) and anti-rabbit Ig, horseradish peroxidase (HRP) linked whole antibody (GE Healthcare U.K. Ltd., Buckinghamshire, England) and anti-rabbit Ig (whole molecule) fluorescein isothiocyanate (FITC) conjugate (SigmaAldrich) were used.

Production of Pycnidione Pycnidione was purified from the culture broth of Gloeotinia sp. FKI-3416, isolated from a soil sample collected at Amamiooshima, Kagoshima, Japan. Briefly, the whole culture broth $(2.0 \mathrm{~L})$ was extracted with ethanol $(2.0 \mathrm{~L})$, concentrated by evaporation to remove the organic solvent, and re-extracted with ethyl acetate. The extract (540 mg) was purified by HPLC using an octadecyl silica column, giving pure pycnidione $(67.8 \mathrm{mg})$.

Cell Culture Jurkat, a human T-cell leukemia-derived cell line was kindly provided by Dr. Kawabe. Jurkat cells were cultured in RPMI1640 containing 10\% FBS and penicillin $(100$ units $/ \mathrm{mL}) /$ streptomycin $(100 \mathrm{mg} / \mathrm{mL})$. The 39 human cancer cell lines for the panel are listed as follows ${ }^{26)} 7$ lung cancers, NCI-H23, NCI-H226, NCI-H522, NCI-H460, A549, DMS273, and DMS114; 5 colorectal cancers, HCC-2998, KM12, HT-29, HCT-15, and HCT-116; 6 gastric cancers, MKN-1, MKN-7, MKN-28, MKN-45, MKN-74, and St-4; 5 ovarian cancers, OVCAR-3, OVCAR-4, OVCAR-5, OVCAR-8, and SK-OV-3; 5 breast cancers, BSY-1, HBC-4, HBC-5, MDAMB-231, and MCF-7; 2 renal cancers, RXF-631L and ACHN; 1 melanoma, LOX-IMVI; 6 gliomas, U251, SF-295, SF-539, SF-268, SNB-75, and SNB-78; and 2 prostate cancers, DU145 and PC-3. These cell lines were cultured in RPMI 1640 medium (Nissui Pharmaceutical, Tokyo, Japan) with 5\% fetal bovine serum, penicillin (100 units $/ \mathrm{mL}$ ), and streptomycin $(100 \mu \mathrm{g} / \mathrm{mL})$ at $37^{\circ} \mathrm{C}$.

MTT Assay Jurkat cells $\left(5.0 \times 10^{5}\right.$ cells $\left./ \mathrm{mL}\right)$ were treated with pycnidione in the presence or absence of bleomycin for $24 \mathrm{~h}$. MTT $(5.0 \mu \mathrm{g} / \mathrm{mL})$ was added and cells were incubated for approximately $3 \mathrm{~h}^{22)}$ After the cells were lysed with $40 \% \mathrm{~N}, \mathrm{~N}$ dimethylformamide, $20 \%$ sodium dodecyl sulfate (SDS), $2.0 \%$ acetic acid, and $0.030 \%$ hydrochloric acid, the absorbance of the solution was read at $600 \mathrm{~nm}$ using POWER WAVE X340
(Bio-Tek Instruments, Winooski, VT, U.S.A.).

Determination of Cell Growth Inhibition Profiles Growth inhibition experiments were performed to assess the sensitivity of the cells to pycnidione as described before. ${ }^{26)}$ Growth inhibition was measured by determining changes in the amounts of total cellular proteins after $48 \mathrm{~h}$ of chemical treatment using a sulforhodamine $\mathrm{B}$ assay. This $\mathrm{GI}_{50}$ calculation method is well-established and reliable for anticancer drug screening using NCI60 as well as JFCR39. ${ }^{26)}$ At each test concentration, the percentage growth was calculated using the following seven absorbance measurements: growth at time 0 $\left(T_{0}\right)$, growth of control cells $(C)$, and test growth in the presence of five different concentrations $(T)$ of a drug. Percentage growth inhibition was calculated as: $\%$ growth $=100 \times\left[\left(T-T_{0}\right) /\right.$ $\left.\left(C-T_{0}\right)\right]$ when $T \geq T_{0}$, and $\%$ growth $=100 \times\left[\left(T-T_{0}\right) / T\right]$ when $T<T_{0}$. $\mathrm{GI}_{50}$ values, which represent $50 \%$ growth inhibition concentration, were calculated as $100 \times\left[\left(T-T_{0}\right) /\left(C-T_{0}\right)\right]=50$. Absolute values of $\mathrm{GI}_{50}$ were then $\log$ transformed for further analysis. We confirmed the accuracy of the measured $\mathrm{GI}_{50}$ data using reference control chemicals, such as mitomycin $\mathrm{C}$, paclitaxel, and SN-38, in each experiment and by checking the dose-response curves.

Hierarchical Clustering Hierarchical clustering analysis was carried out using the average linkage method and "GeneSpring" software (Silicon Genetics, Inc., Redwood, CA, U.S.A.). Pearson correlation coefficients were used to determine the degree of similarity.

Cell Cycle Analysis Jurkat cells were stained with Krishan's solution ${ }^{22)}(0.20 \%$ sodium citrate, $100 \mathrm{mg} / \mathrm{mL}$ propidium iodide, $40 \mathrm{mg} / \mathrm{mL}$ ribonuclease A, 0.60\% IGEPAL CA-630). The cell cycle status was determined by analyzing the DNA content using flow cytometry (FACSCalibur; Becton Dickinson, San Jose, CA, U.S.A.) with CELL Quest software. Ten thousand cells were analyzed and the distribution ratios in each phase (Sub G1, G1, S and G2/M) were calculated.

Phospho-Histone H2A.X Analysis The assay to detect phospho-histone H2A.X was performed according to the instructions for the phospho-Histone H2A.X (Ser139) antibody. Briefly, Jurkat cells were fixed with $2.5 \%$ formaldehyde for $10 \mathrm{~min}$ at room temperature, chilled on ice for $1.0 \mathrm{~min}$, permeabilized with $90 \%$ ice-cold $\mathrm{MeOH}$, and kept at $4{ }^{\circ} \mathrm{C}$ for $30 \mathrm{~min}$. The cells were stained with phospho-Histone H2A.X (Ser139) primary antibody for $1.0 \mathrm{~h}$, further stained with anti-rabbit FITC conjugated antibody for $1.0 \mathrm{~h}$, and counterstained with propidium iodide (Krishan's solution) for $20 \mathrm{~min}$.

Western Blotting Jurkat cell lysates were prepared with Triton lysis buffer $(50 \mathrm{~mm}$ Tris- $\mathrm{HCl}, \mathrm{pH} 7.4,10 \%$ glycerol, $1.0 \%$ Triton X-100, $1.0 \mathrm{~mm}$ ethylenediaminetetraacetic acid (EDTA), and $150 \mathrm{~mm}$ sodium chloride) containing protease inhibitors $(5.0 \mathrm{mg} / \mathrm{mL}$ aprotinin, $5.0 \mathrm{mg} / \mathrm{mL}$ leupeptin, $5.0 \mathrm{mg}$ / $\mathrm{mL}$ pepstatin, $5.0 \mathrm{mg} / \mathrm{mL}$ sodium orthovanadate, and $0.50 \mathrm{~mm}$ phenylmethanesulfonyl fluoride). ${ }^{27)}$ Total cell protein $(20 \mu \mathrm{L})$ was subjected to sodium dodecyl sulfate-polyacrylamide gel electrophoresis (SDS-PAGE) on 10\% polyacrylamide gels and electrotransferred onto polyvinylidene difluoride membranes (Millipore). The secondary antibody was visualized using ECL Western Blotting Detection Reagents (GE Healthcare) and detected by LAS-4000 mini using Science Lab 2005 software (Fujifilm Co., Tokyo, Japan). Sequential reprobing of membranes with a variety of antibodies was performed after inactivation of HRP with $0.10 \%$ sodium azide or after the 
complete removal of primary and secondary antibodies from the membrane in stripping buffer, according to the manufacturer's instructions.

Synthesis of $\boldsymbol{O}$-Dimethylpycnidione A solution of pycnidione $(5.3 \mathrm{mg}, 9.7 \mathrm{nmol})$ in benzene/MeOH $(1: 1,0.50 \mathrm{~mL})$ was treated with (trimethylsilyl)diazomethane $(2.0 \mathrm{M}$ in hexane, $14 \mu \mathrm{L}, 28 \mathrm{nmol})$ at $0^{\circ} \mathrm{C}$, and the mixture was stirred at $0^{\circ} \mathrm{C}$ for $30 \mathrm{~min}$. Acetic acid was added, and the reaction mixture was concentrated in vacuo. The residue $(6.2 \mathrm{mg})$ was finally purified by preparative HPLC (column; PEGASIL ODS (Senshu Scientific Co., Ltd., Tokyo, Japan), 4.6×250 mm; solvent, 40\% acetonitrile; detection, $\mathrm{UV}$ at $210 \mathrm{~nm}$; flow rate, $1.0 \mathrm{~mL} / \mathrm{min}$ ). Under these conditions, $O$-dimethylated pycnidiones D1 to D4 were eluted as peaks with retention times of 13.2, 16.2, 19.0 and $24.0 \mathrm{~min}$, respectively. The fractions were concentrated in vacuo to dryness to give pure $O$-dimethylpycnidiones D1 $(0.60 \mathrm{mg}), \mathrm{D} 2(0.60 \mathrm{mg}), \mathrm{D} 3(0.60 \mathrm{mg})$ and D4 $(0.71 \mathrm{mg})$ as white crystals. D1: ${ }^{1} \mathrm{H}-\mathrm{NMR}$ (deuterochloroform, $\left.400 \mathrm{MHz}\right) \delta$ : 7.00 (s, 2H), 6.52 (s, 2H), 5.36-5.35 (m, 2H), 3.92 (s, 3H), 3.91 (s, 3H), 3.57-3.54 (m, 1H), 3.05 (dd, $1 \mathrm{H}, J=4.4,16.0 \mathrm{~Hz}), 2.70$ (dd, $1 \mathrm{H}, J=5.2,17.6 \mathrm{~Hz}), 2.68-2.65(\mathrm{~m}, 1 \mathrm{H}), 2.42(\mathrm{~s}, 3 \mathrm{H}), 2.39$ (s, 3H), $2.45-2.26(\mathrm{~m}, 3 \mathrm{H}), 2.18(\mathrm{~d}, 1 \mathrm{H}, J=4.0 \mathrm{~Hz}), 1.87-1.84$ $(\mathrm{m}, 1 \mathrm{H}), 1.75-1.50(\mathrm{~m}, 3 \mathrm{H}), 1.26(\mathrm{~s}, 3 \mathrm{H}), 1.23(\mathrm{~s}, 3 \mathrm{H}), 1.09$ $(\mathrm{s}, 3 \mathrm{H}), 1.05(\mathrm{~s}, 3 \mathrm{H}), 1.22-1.03(\mathrm{~s}, 2 \mathrm{H})$; low resolution mass spectrum (LR-MS), m/z $577\left(\mathrm{M}+\mathrm{H}^{+}\right)$. D2: ${ }^{1} \mathrm{H}-\mathrm{NMR}$ (deuterochloroform, $400 \mathrm{MHz}) \delta$ : $7.03(\mathrm{~s}, 1 \mathrm{H}), 6.89(\mathrm{~s}, 1 \mathrm{H}), 6.50(\mathrm{~s}$, $1 \mathrm{H}), 6.46(\mathrm{~s}, 1 \mathrm{H}), 5.41-5.37(\mathrm{~m}, 2 \mathrm{H}), 3.92(\mathrm{~s}, 3 \mathrm{H}), 3.91(\mathrm{~s}$, $3 \mathrm{H}), 3.70-3.50(\mathrm{~m}, 1 \mathrm{H}), 3.20-3.28(\mathrm{~m}, 1 \mathrm{H}), 2.69-2.61(\mathrm{~m}$, 2H), 2.41 (s, 3H), 2.38 (s, 3H), 2.40-2.32 (m, 3H), 2.18-2.16 $(\mathrm{m}, 1 \mathrm{H}), 1.83-1.75(\mathrm{~m}, 1 \mathrm{H}), 1.75-1.50(\mathrm{~m}, 3 \mathrm{H}), 1.35(\mathrm{~s}, 3 \mathrm{H})$, $1.23(\mathrm{~s}, 3 \mathrm{H}), 1.18(\mathrm{~s}, 3 \mathrm{H}), 1.09$ (s, 3H), 1.17-1.03 (s, 2H); LR-MS, m/z $577\left(\mathrm{M}+\mathrm{H}^{+}\right)$. D3: ${ }^{1} \mathrm{H}-\mathrm{NMR}$ (deuterochloroform, $400 \mathrm{MHz}) \delta: 7.04(\mathrm{~s}, 1 \mathrm{H}), 6.91(\mathrm{~s}, 1 \mathrm{H}), 6.51(\mathrm{~s}, 1 \mathrm{H}), 6.45(\mathrm{~s}$, $1 \mathrm{H}), 5.42-5.30(\mathrm{~m}, 2 \mathrm{H}), 3.92(\mathrm{~s}, 3 \mathrm{H}), 3.89(\mathrm{~s}, 3 \mathrm{H}), 3.60-3.55$ $(\mathrm{m}, 1 \mathrm{H}), 2.85(\mathrm{dd}, 1 \mathrm{H}, J=5.2,17.2 \mathrm{~Hz}), 2.73-2.62(\mathrm{~m}, 2 \mathrm{H})$, $2.39(\mathrm{~s}, 3 \mathrm{H}), 2.34(\mathrm{~s}, 3 \mathrm{H}), 2.42-2.17(\mathrm{~m}, 3 \mathrm{H}), 2.03-2.01(\mathrm{~m}$, $1 \mathrm{H}), 1.93-1.91(\mathrm{~m}, 1 \mathrm{H}), 1.90-1.80(\mathrm{~m}, 3 \mathrm{H}), 1.30(\mathrm{~s}, 3 \mathrm{H}), 1.29$ (s, 3H), 1.20 (s, 3H), 1.07 (s, 3H), 1.32-1.06 (s, 2H); LR-MS, $\mathrm{m} / \mathrm{z} 577\left(\mathrm{M}+\mathrm{H}^{+}\right)$. D4: ${ }^{1} \mathrm{H}-\mathrm{NMR}$ (deuterochloroform, $400 \mathrm{MHz}$ ) $\delta: 7.03(\mathrm{~s}, 1 \mathrm{H}), 7.02(\mathrm{~s}, 1 \mathrm{H}), 6.48(\mathrm{~s}, 1 \mathrm{H}), 6.46(\mathrm{~s}, 1 \mathrm{H}), 5.51-$ $5.40(\mathrm{~m}, 2 \mathrm{H}), 3.93(\mathrm{~s}, 3 \mathrm{H}), 3.91(\mathrm{~s}, 3 \mathrm{H}), 3.74-3.68(\mathrm{~m}, 1 \mathrm{H})$, $2.98-2.91(\mathrm{~m}, 1 \mathrm{H}), 2.72(\mathrm{dd}, 1 \mathrm{H}, J=3.6,13.2 \mathrm{~Hz}), 2.64$ (dd, $1 \mathrm{H}, J=5.6,17.6 \mathrm{~Hz}), 2.37$ (s, 3H), 2.37 (s, 3H), 2.47-2.09 (m, $4 \mathrm{H}), 1.89-1.80(\mathrm{~m}, 1 \mathrm{H}), 1.78-1.43(\mathrm{~m}, 3 \mathrm{H}), 1.25(\mathrm{~s}, 3 \mathrm{H}), 1.23$ (s, 3H), 1.12 (s, 3H), 1.08 (s, 3H), 1.17-1.01 (s, 2H); LR-MS, $\mathrm{m} / \mathrm{z} 577\left(\mathrm{M}+\mathrm{H}^{+}\right)$.

\section{RESULTS}

Abrogation of Bleomycin-Induced G2 Arrest in Jurkat Cells by Pycnidione First, we prepared the concentrations of bleomycin and colchicines for cell cycle analysis using Jurkat cells. In cells treated with bleomycin $(30 \mu \mathrm{g} / \mathrm{mL})$ for $24 \mathrm{~h}$, the distribution ratios in the Sub G1 and G2/M were $12.4 \%$ and $72.2 \%$, respectively, and cell viability was $88.9 \%$, indicating that $30 \mu \mathrm{g} / \mathrm{mL}$ bleomycin arrested the cell cycle at the $\mathrm{G} 2$ phase (Fig. 1B). Furthermore, in combination with caffeine (3.0 mM), a G2 checkpoint abrogator, ${ }^{16)}$ bleomycin-induced G2 arrest was abrogated. Similarly, when cells were treated with colchicine $(10 \mathrm{ng} / \mathrm{mL})$, the ratios in the Sub G1 and G2/M were $18.6 \%$ and $60.0 \%$, respectively, indicating that $10 \mathrm{ng} / \mathrm{mL}$ col- chicine arrested the cell cycle at the M phase (Fig. 1C). Thus, we used $30 \mu \mathrm{g} / \mathrm{mL}$ bleomycin and $10 \mathrm{ng} / \mathrm{mL}$ colchicine in our cell cycle experiments.

The effect of pycnidione on bleomycin-induced G2 arrest or colchicine-induced $\mathrm{M}$ phase arrest in Jurkat cells was tested (Fig. 1D). Pycnidione alone did not change the distribution in the Sub G1, G1, S and G2/M up to $255 \mathrm{~nm}$. With a combination of pycnidione $(27-255 \mathrm{~nm})$ and bleomycin, the cell cycle pattern changed markedly. Cells in the Sub G1 phase increased, and conversely, cells in the G2 phase decreased in a dose-dependent manner. On the other hand, pycnidione had no effect on colchicine-induced $M$ phase arrest in Jurkat cells. These data indicate that pycnidione selectively abrogated bleomycin-induced G2 arrest.

Next, we tried to remove the pycnidione by washing the cells. Jurkat cells were pretreated with pycnidione $(255 \mathrm{~nm})$ for $3 \mathrm{~h}$, and then cells were washed with PBS to remove pycnidione in the medium. Pycnidione-pretreated cells were incubated in the presence of bleomycin $(30 \mu \mathrm{g} / \mathrm{mL})$ for $24 \mathrm{~h}$, and the cell cycle status was analyzed. As shown in Fig. 1E, pretreatment still caused the abrogation of bleomycin-induced G2 arrest, suggesting that pycnidione strongly bound to target(s) in Jurkat cells.

Effect of Pycnidione on Cyclin Levels in BleomycinTreated Jurkat Cells When cells were arrested at the G2 phase, it was reported that cyclin D3 levels were moderately increased, and the levels of cyclins $\mathrm{A}$ and B1 were markedly increased ${ }^{28,29)}$; therefore, the protein levels of CDK/cyclin complex were analyzed (Fig. 2). In bleomycin-treated cells, the protein levels of cyclins D3, A and B1 were increased (Fig. 2, lane 3), indicating that Jurkat cells were arrested at the G2 phase, while in combination with pycnidione (lane 4), the levels of cyclins D3, A and B1 decreased to similar levels to untreated control cells (lane 1), indicating that cells were not arrested at the G2 phase.

Synergistic Potentiation of Bleomycin Cytotoxicity to Jurkat Cells in Combination with Pycnidione It is well known that G2 checkpoint abrogators increase the cytotoxicity of DNA-damaging anticancer agents. ${ }^{16,18-20)}$ Pycnidione alone (Fig. 3A) or bleomycin alone (Fig. 3B) inhibited cell proliferation in a dose-dependent manner with an $\mathrm{IC}_{50}$ value of $510 \mathrm{~nm}$ or $100 \mu \mathrm{g} / \mathrm{mL}$, respectively. Note that $100 \mathrm{~nm}$ pycnidione did not show marked cytotoxicity (Figs. 1B, 3A). In the presence of $100 \mathrm{~nm}$ pycnidione, bleomycin more strongly inhibited cell proliferation with an $\mathrm{IC}_{50}$ value of $11 \mu \mathrm{g} / \mathrm{mL}$ (Fig. 3B), indicating that pycnidione potentiated the cytotoxicity of bleomycin to Jurkat cells 9.2-fold. Interestingly, the potentiating effect of pycnidione was attenuated in the presence of MG132 (Fig. $3 \mathrm{~B}$ ), a specific proteasome inhibitor, ${ }^{30)}$ indicating that the proteasome pathway was involved in the pycnidione-dependent potentiation of bleomycin activity.

To investigate the existence of a possible synergistic effect, isobologram analysis of the two-drug interaction was performed. ${ }^{31)}$ As shown in Fig. 3C, data points of bleomycin $(30 \mu \mathrm{g} / \mathrm{mL})$ and pycnidione $(0-255 \mathrm{~nm})$ were plotted below the solid line, indicating that the interaction between pycnidione and bleomycin is synergistic. Next, we investigated the mechanism of action of this synergistic effect.

Effect of Pycnidione on Phosphorylation Levels of Histone H2A.X DNA damage caused by bleomycin, ionizing radiation or radiomimetic agents results in rapid phosphoryla- 
A CDK6/Cyclin D3

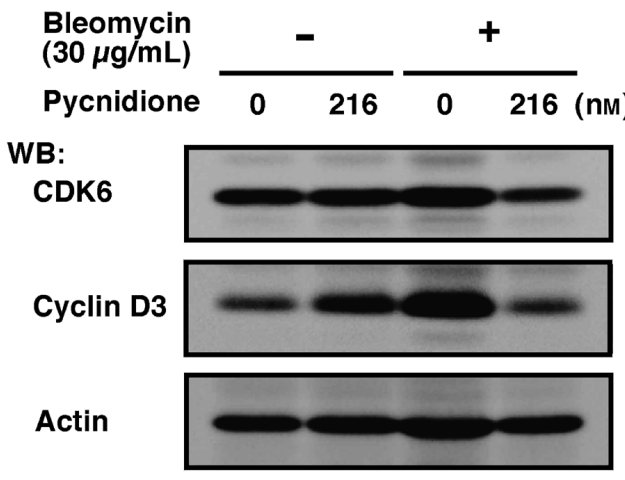

\section{B CDK2/Cyclin A}

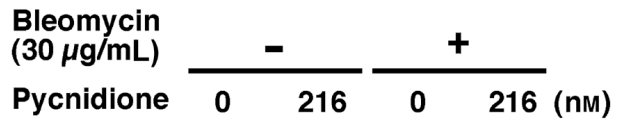

WB:

CDK2

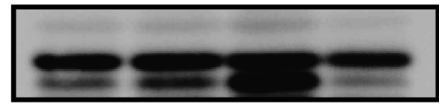

Cyclin A

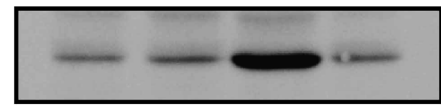

Actin

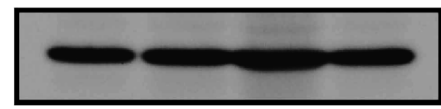

\section{CDK1/Cyclin B1}

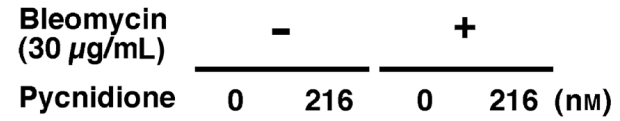

WB:

CDK1

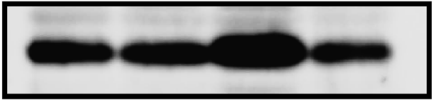

Cyclin B1

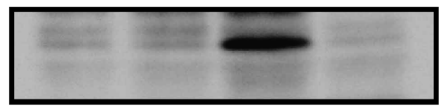

Actin

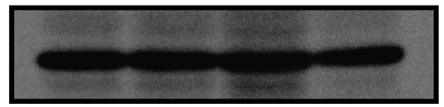

Fig. 2. Effect of Pycnidione on CDK6, Cyclin D3, CDK2, Cyclin A, CDK1 and Cyclin B1 Levels

Equal amounts of cell lysates prepared from Jurkat cells $\left(5.0 \times 10^{5}\right.$ cells $\left./ \mathrm{mL}\right)$ cultured in the absence or presence of pycnidione and/or in combination with bleomycin for $24 \mathrm{~h}$ were subjected to SDS-PAGE and Western blotting.

tion of the histone H2A family member H2A.X at Ser139 by ATM. $^{32,33)}$ Therefore, phospho-histone H2A.X (Ser139) levels were analyzed to investigate whether bleomycin-induced DNA damage occurs in the presence of pycnidione (Fig. 4A). When Jurkat cells were treated with pycnidione alone, the phosphorylation levels of histone H2A.X $(1.0-2.3 \%$ of total cells) were not increased even at $255 \mathrm{~nm}$. On the other hand, in bleomyin-treated cells, the levels increased to $7.4 \%$. Fur-
A

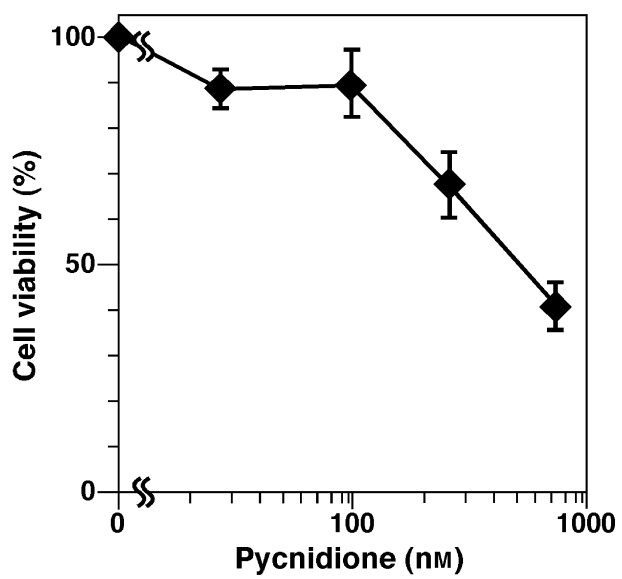

B
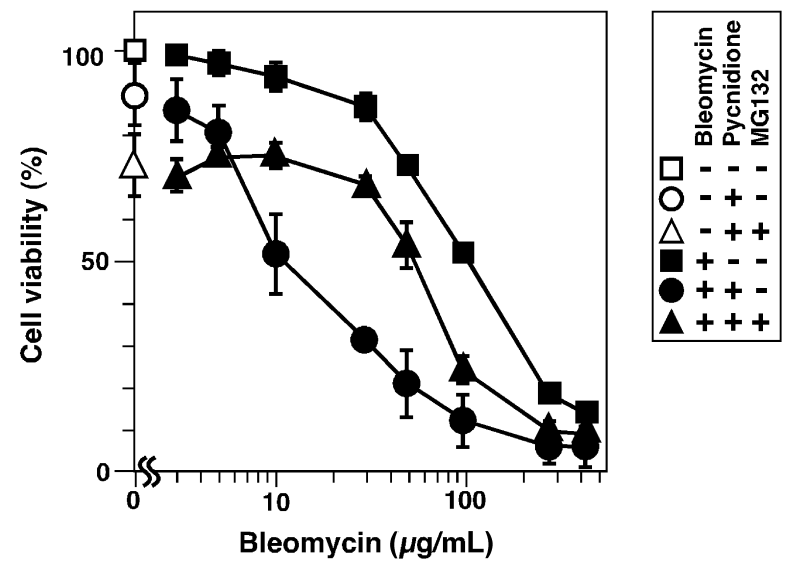

C

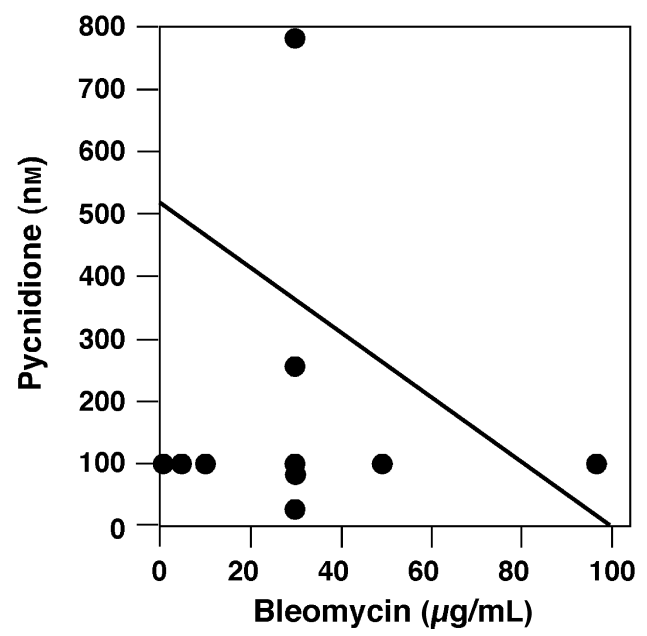

Fig. 3. Pycnidione Potentiated Cytotoxicity of Bleomycin in Jurkat Cells

(A) Jurkat cells $\left(5.0 \times 10^{5}\right.$ cells $\left./ \mathrm{mL}\right)$ were incubated with pycnidione alone for $24 \mathrm{~h}$. Cell viability was evaluated by MTT assay. Each value represents the mean \pm S.D. of three independent experiments. (B) Jurkat cells $\left(5.0 \times 10^{5}\right.$ cells $\left./ \mathrm{mL}\right)$ were incubated with/without bleomycin, with/without $100 \mathrm{~nm}$ pycnidione and with/without $1 \mu \mathrm{M}$ MG132 for $24 \mathrm{~h}$. Cell viability was evaluated by MTT assay. Each value represents the mean \pm S.D. of six independent experiments. (C) Effects of combined pycnidione and bleomycin in Jurkat cells. Isobolograms at $\mathrm{IC}_{50}$ based on the results of MTT assays of Jurkat cells treated with pycnidione and bleomycin are shown. The data represent the average of six experiments. 
A a) Vehicle + pycnidione (0 - $255 \mathrm{~nm})$

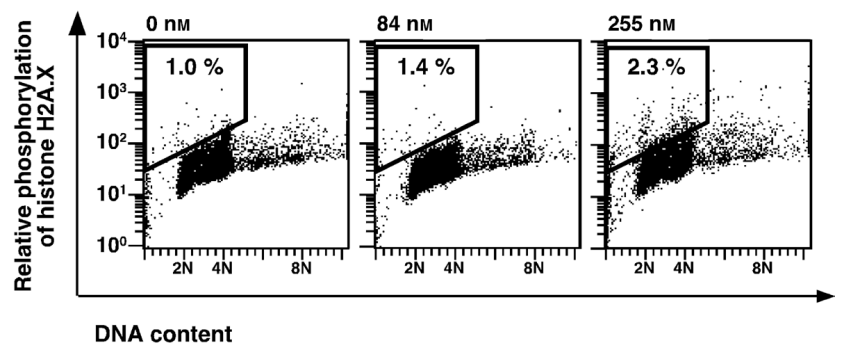

b) Bleomycin $(30 \mu \mathrm{g} / \mathrm{mL})+$ pycnidione (0 - $255 \mathrm{~nm})$

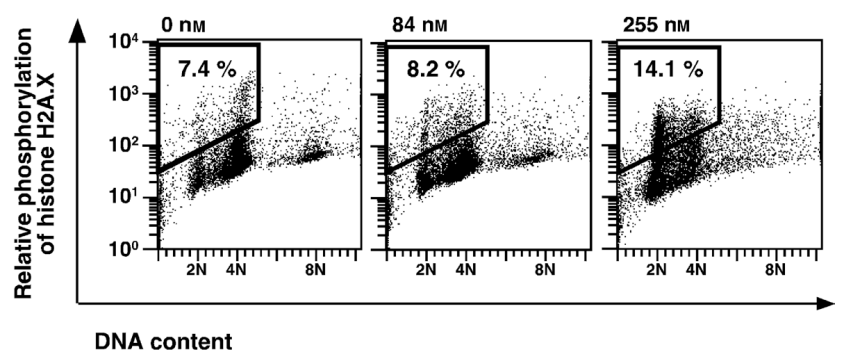

B

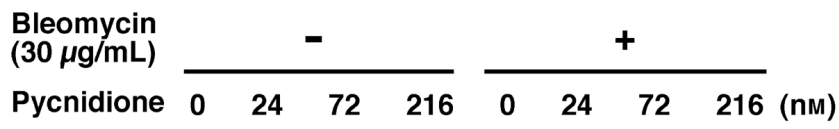

WB:
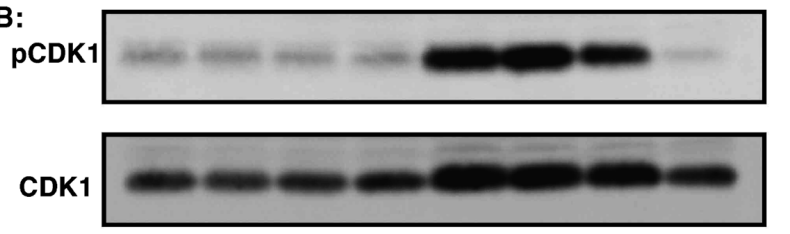

C

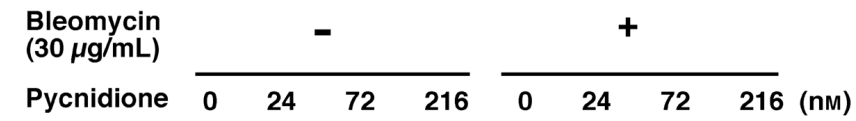

WB:

Chk1

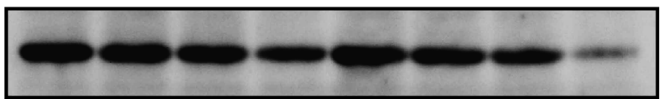

Chk2
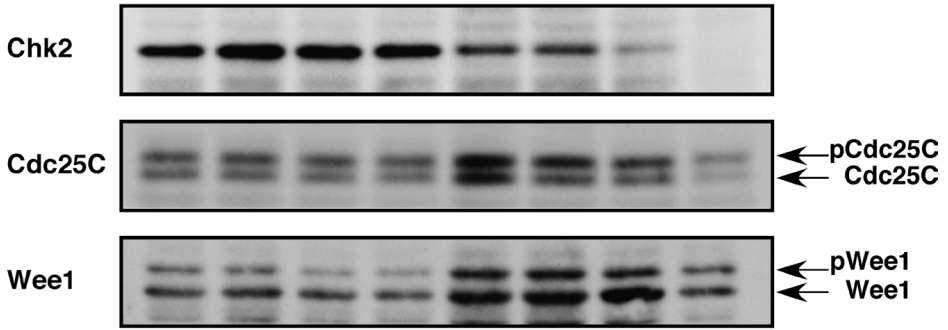

CDK1

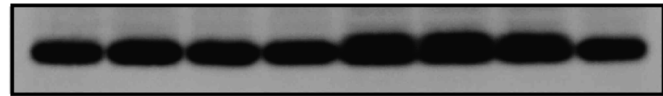

Actin

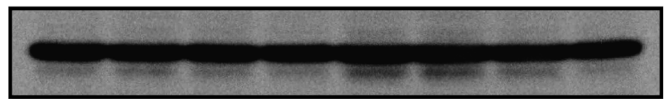

Fig. 4. Effect of Pycnidione on the Signal Transducers of DNA Damage-Induced G2 Arrest

(A) Jurkat cells $\left(1-2 \times 10^{5}\right.$ cells $\left./ \mathrm{mL}\right)$ were incubated with pycnidione alone (a) or in combination with bleomycin (b) for $24 \mathrm{~h}$. After incubation, the cells were fixed and stained with anti-phospho-Histone H2A.X (Ser139) antibody and analyzed by flow cytometer. DNA content (propidium iodide) was plotted on the $x$-axis and phosphorylated H2A.X (FITC) was plotted on the $y$-axis. (B) Cell lysates were prepared from Jurkat cells $\left(2.5-5.0 \times 10^{5}\right.$ cells $\left./ \mathrm{mL}\right) \mathrm{cultured}$ in the absence or presence of pycnidione and/or with bleomycin for $24 \mathrm{~h}$. The relative phosphorylation levels of CDK1 in bleomycin-treated cells were calculated, normalized to the levels of total CDK1, and only bleomycin-treated cells were set as a control (1.00). (C) Cell lysates were prepared from Jurkat cells $\left(2.5-5.0 \times 10^{5}\right.$ cells $\left./ \mathrm{mL}\right)$ cultured in the absence $($ lanes $1-4)$ or presence (lanes 5-8) of pycnidione and/or with bleomycin for $24 \mathrm{~h}$. 
thermore, in combination with pycnidione, the levels further increased in a pycnidione-dependent manner. These results indicated that the DNA damage signal driven by bleomycin was not disrupted by pycnidione.

Decrease in Phosphorylation Levels of CDK1 by Pycnidione The entry of eukaryotic cells into mitosis is regulated by CDK1 kinase activation, a process controlled at several steps, including cyclin binding and phosphorylation of CDK1 at Tyr15.') Therefore, the phosphorylation levels of CDK1 were examined (Fig. 4B). The levels were very low in the absence or presence of pycnidione without bleomycin, indicating that pycnidione itself had no effect on phosphorylation. When the cells were treated with bleomycin, the phosphorylation levels significantly increased to arrest cells at the G2 phase. ${ }^{9)}$ Under these conditions, the combination with pycnidione led to a decrease in phosphorylated CDK1 levels driven by bleomycin. When the ratio (pCDK1 vs. CDK1) in bleomycin-treated cells was defined as 1.00 (lane 5), the ratio in cells in combination with pycnidione (lane 8 ) was estimated to be 0.10 , the same as in untreated cells. These results indicate that cells abrogated G2 arrest to progress the cell cycle. Taken together, pycnidione blocks signal transduction between ATM and CDK1, leading to the abrogation of bleomycin-induced G2 arrest.

Effect of Pycnidione on the Levels of Proteins Involved in G2 Arrest Signal Transduction Induced by Bleomycin At the G2 checkpoint, a DNA damage signal from ATM is transmitted through the downstream proteins, Chk1, Chk2, $\mathrm{Cdc} 25 \mathrm{C}$, Weel and $\mathrm{CDK}^{4-6,8-10)}$; therefore, the levels of these proteins were examined (Fig. 4C). Compared with those in bleomycin-treated cells (lane 5), the levels of Chk1 and Chk2 in cells treated with bleomycin in combination with pycnidione (216nM) markedly fell to $16 \%$ and $13 \%$ (lane 8 ), respectively. Thus, the down-regulation of Chk1 and Chk2 levels reduced the phosphorylation of CDK1 (Fig. 4B), leading to abrogation of bleomycin-induced G2 arrest by pycnidione. As described above (Fig. 2), the levels of proteins involved in other phases of the cell cycle, such as CDK6, CDK2 and CDK1, were not affected by treatment with pycnidione alone (lane 2) or with bleomycin and pycnidione (lane 4). These results indicate that pycnidione abrogated bleomycin-induced G2 arrest by decreasing the Chk1 and Chk2 levels.

Human Cancer Cell Line Panel Experiment To search for the molecular target of pycnidione, the compound was evaluated in a human cancer cell line panel (COMPARE analysis), ${ }^{26)}$ in which values giving $50 \%$ inhibition $\left(\mathrm{IC}_{50}\right)$ of pycnidione against the growth of 39 human cancer cell lines (mean graphs) were measured (Fig. 5A), and the pattern was compared with those of typical anticancer agents with different mechanisms of action (Fig. 5B). Fingerprint pattern analysis revealed that the top drug in the rank order of correlation coefficients is ellipticine $(r=0.656)$, a topoisomerase II inhibitor. ${ }^{34)}$ And the second drug is carmofur $(r=0.544)$, of which the mode of action is still controversial in terms of the blocking of DNA phosphorylation through inhibition of thymidylate synthetase or the destortion of gene expression after incorporation of fluoropyrimidines into RNA. ${ }^{35)}$ However, the correlation coefficient between carmofur and pycnidione was too low to be relied on.

Importance of Tropolone Backbone in Pycnidione for G2 Arrest Abrogative Activity Epolone A (Fig. 6A) with a structure in which one tropolone moiety in pycnidone was replaced for a benzene moiety had almost no effect on bleomycin-induced G2 arrest up to $0.96 \mu \mathrm{M}$ (data not shown), suggesting that the presence of two tropolones is important for activity. To confirm this point, pycnidione was treated with diazomethane $^{36)}$ to produce four $O$-dimethyl derivatives D1 to D4 (Fig. 6B). As shown in Fig. 6C, none of the derivatives exhibited marked abrogation activity of bleomycin-induced G2 arrest. These results indicate that the presence of two tropolone backbones in pycnidone was important for the abrogation activity of bleomycin-induced G2 arrest.

\section{DISCUSSION}

Pycnidione abrogated bleomycin-induced G2 arrest in Jurkat cells and synergically potentiated the cytotoxicity of bleomycin (Fig. 2), leading to the death of Jurkat cells (Fig. 3) and several cancer cells (Fig. 5). These results indicate that pycnidione has ideal characteristics as a G2 checkpoint abrogator; therefore, we elucidated the mechanism of action in this study. First, we investigated the levels of six molecules, ATM/ ATR, CDK1, Chk1, Chk2, Cdc25C and Wee1, involved in bleomycin-induced G2 arrest signal transduction as potential targets of pycnidione. In bleomycin-treated cells, the protein levels of Chk2 were decreased, while in pycnidione-treated cells, the levels of Chk1 were decreased (Fig. 4C). Furthermore, the concomitant treatment of bleomycin and pycnidione severely reduced the levels of Chk1 and Chk2. Therefore, we concluded that the abrogation of bleomycin-induced G2 arrest by pycnidione was caused by decrease in the levels of Chk1 and Chk2.

From the results of COMPARE analysis, we investigated whether pycnidione inhibits topoisomerases. Interestingly, pycnidione was found to inhibit topoisomerase II activity with an $\mathrm{IC}_{50}$ value of $19 \mu \mathrm{M}$ (data not shown), and also to weakly inhibit topoisomerase I activity (data not shown). Therefore, topoisomerases might be potential targets of pycnidione action although two problems were mentioned; 1) the $\mathrm{IC}_{50}$ values between cell-based assay and enzyme assay had large differences, 2) unfortunately, ellipticine potentiated the cytotoxicity of bleomycin to Jurkat cells only 3.1 times (data not shown). It was reported that ellipticine has the different activity of directly binding to $\mathrm{DNA}^{34)}$; however, pycnidione has no activity to bind DNA because the DNA mobility was not shifted in the presence of pycnidione (data not shown). Therefore, it is plausible that a lack of direct binding activity to DNA may be important for topoisomerase II inhibition to show the abrogation activity of bleomycin-induced G2 arrest.

Topoisomerases play critical roles in DNA metabolism by controlling the topology of DNA. ${ }^{37)}$ Several topoisomerase inhibitors have been reported; NSC 320846 and F11782, inhibitors of topoisomerases I and II, induced cell death ${ }^{33,38)}$ and H2A.X phosphorylation, ${ }^{33)}$ and R16, which was an inhibitor of topoisomerase $\mathrm{II}^{39)}$ and an inducer of genotoxic damage similar to bleomycin, ${ }^{40)}$ reduced Chk1 levels. ${ }^{41)}$ As demonstrated, pycnidione also induced cell death (Fig. 3), increased the phosphorylation of H2A.X (Fig. 4), and decreased Chk1 and Chk2 in combination with bleomycin (Fig. 4). Therefore, the decrease of the levels of Chk1 and Chk 2 could be caused by the inhibition of topoisomerses. Recently, Feng et al. reported that the inhibition of topoisomerase II by R16 induced proteasome-dependent degradation of Chk1 without significant 
A
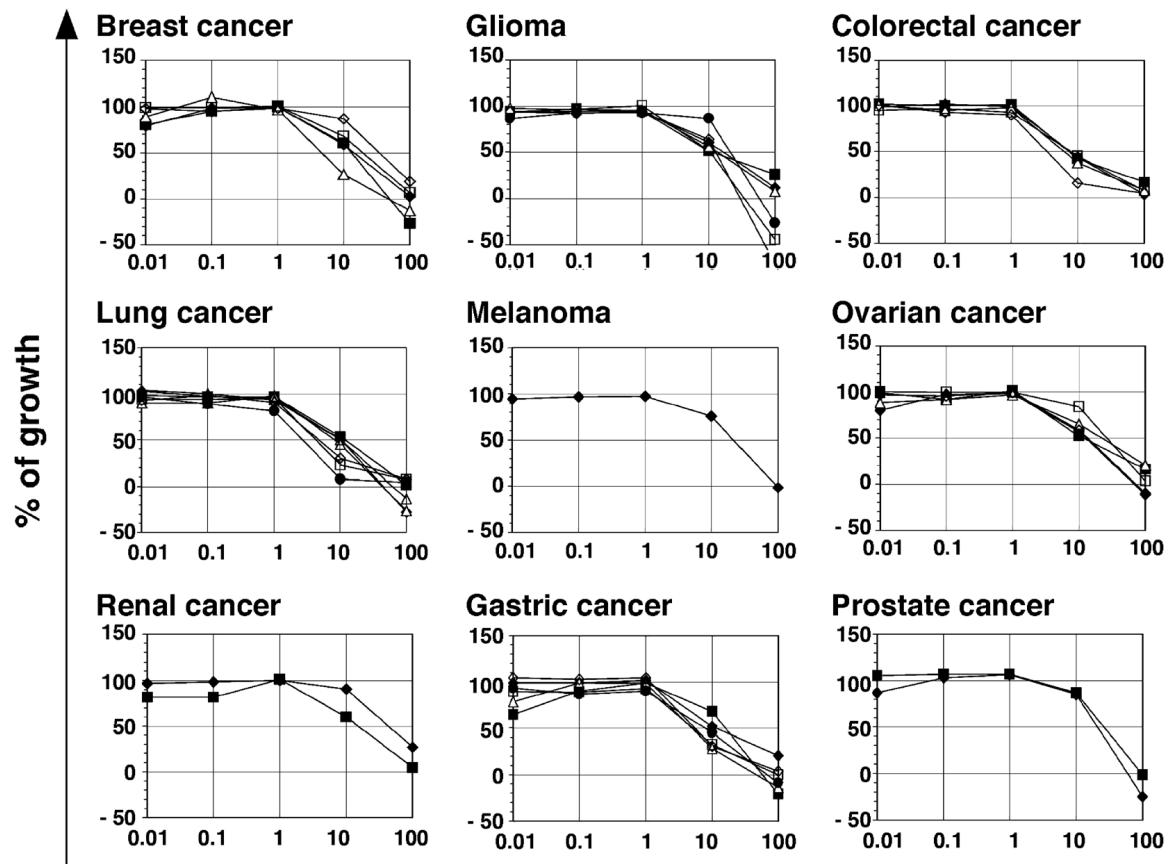

Prostate cancer

\section{Pycnidione (nM)}

B

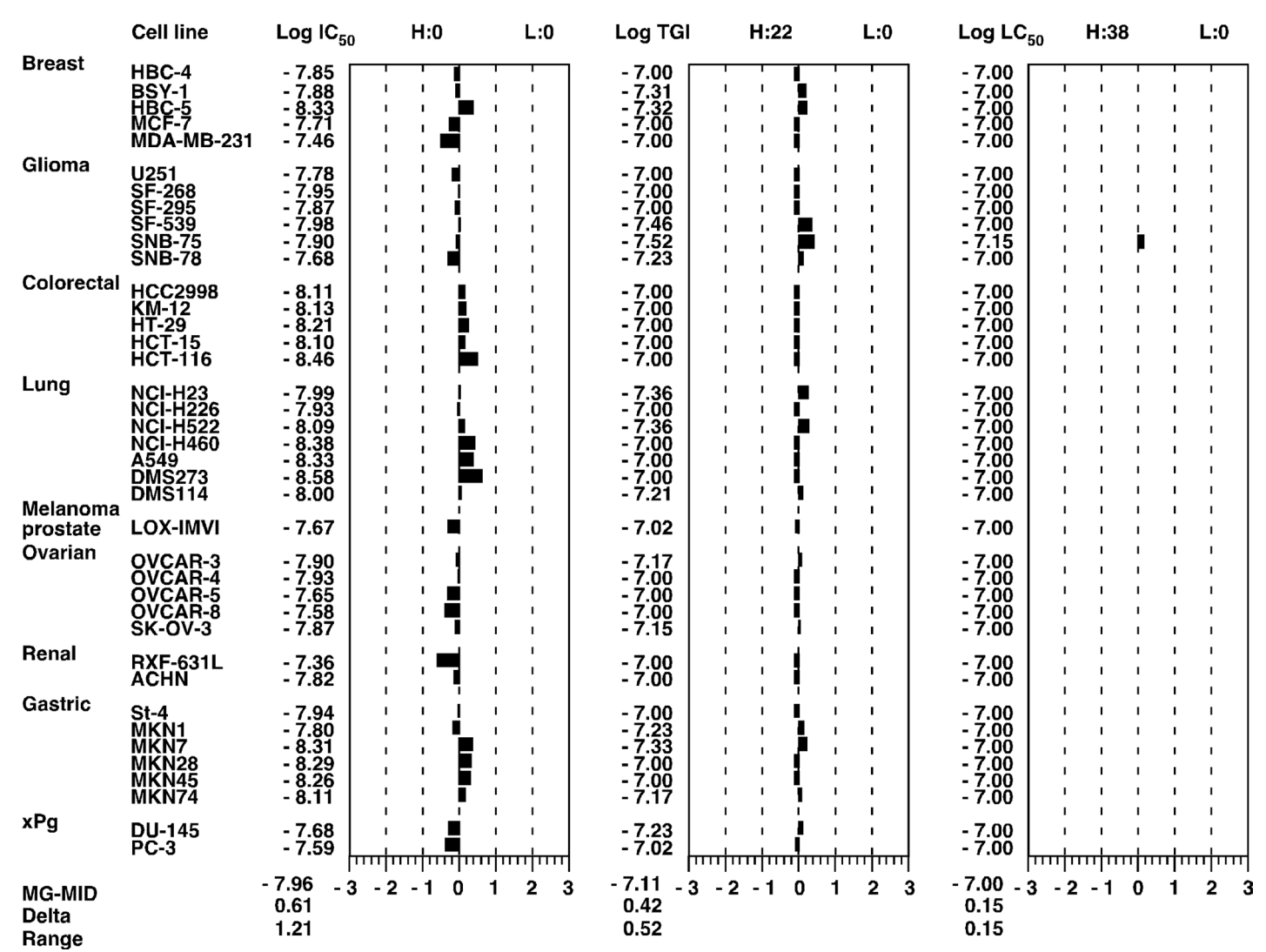

Fig. 5. Anti-cancer Activity of Pycnidione in a Panel of 39 Human Cancer Cell Lines

(A) Dose-response curves of pycnidione against growth of JFCR-39 cells. $x$-Axis shows concentration of pycnidione and $y$-axis shows percentage growth. (B) MG-MID: mean of $\log X$ values $\left(X=\mathrm{IC}_{50}\right.$, TGI, and $\left.\mathrm{LC}_{50}\right)$. Delta: logarithm of the difference between the MG-MID and $\log X$ of the most sensitive cell line. Range: $\operatorname{logarithm}$ of the difference between the $\log X$ of the most resistant cell line and the $\log X$ of the most sensitive cell line. 


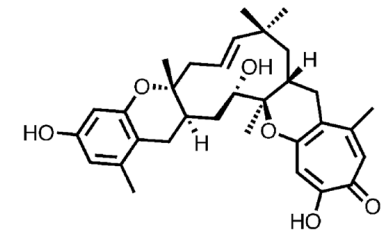

B<smiles></smiles>

D2

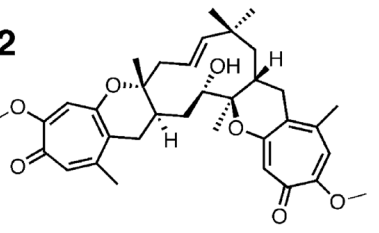

D3

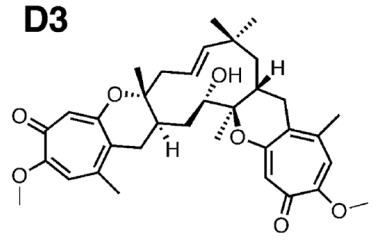

D4

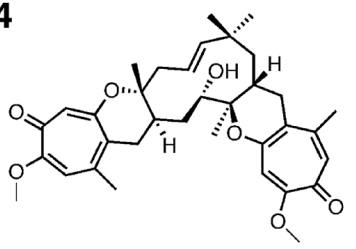

C

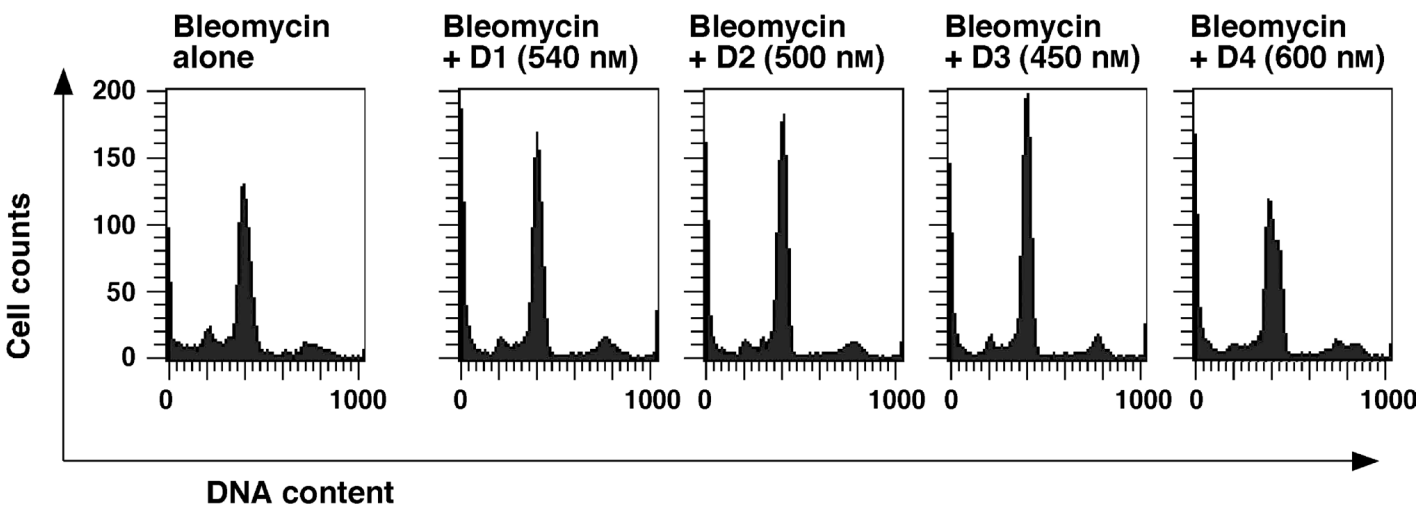

Fig. 6. Effect of $O$-Dimethylpycnidione Derivatives on Topoisomerases

(A) Structure of epolone A. (B) Structures of $O$-dimethylpycnidiones. (C) Jurkat cells $\left(5.0 \times 10^{5} \mathrm{cells} / \mathrm{mL}\right)$ were incubated with $O$-dimethylpycnidione in the presence of $30 \mu \mathrm{g} / \mathrm{mL}$ bleomycin. Distribution in the cell cycle was analyzed by flow cytometry $24 \mathrm{~h}$ after incubation. (D) DNA cleavage activity of human topoisomerase II(a) and I(b) was measured in the presence of the indicated concentration of $O$-dimethylpycnidione using supercoiled plasmid DNA.

alteration of the Chk1 mRNA level. ${ }^{39)}$ Furthermore, genotoxic stress induced by topoisomerase I inhibitor camptothecin triggered Chk1 destruction via the ubiquitin-proteasome pathway, ${ }^{41)}$ and MG132, a proteasome inhibitor, attenuated the potentiating effect of pycnidione (Fig. 3B). These results strongly suggest that pycnidione promotes the proteasome-mediated degradation of Chk1 and Chk2 proteins by inhibiting the topoisomerases.

G2 checkpoint is expected as a potential target to develop a new type of anticancer agent, ${ }^{42}$ and many abrogators of G2 checkpoint have been reported: MK-1775 (Weel inhibitor), ${ }^{43)}$ STI571 (c-Abl kinase inhibitor) ${ }^{44)}$ leptomycin B (Crm1 inhibitor), ${ }^{45)}$ isogranulatimide (Chk1 inhibitors), ${ }^{46)} \mathrm{UCN}-01$ (Chk1 inhibitors), ${ }^{11)}$ Gö6976 (protein kinase $\mathrm{C}$ inhibitor), ${ }^{15)}$ debromohymenialdisine (Chk1 and Chk2 dual inhibitor) ${ }^{47)}$ L-744,832 (farnesyl transferase inhibitor), ${ }^{48)}$ and caffeine (ATM/ATR inhibitor) $^{16)}$; however, no compounds, which decreased the levels of Chk1 and Chk2, have been reported. Therefore, pycnidione is expected to be developed as a new type of agent in combination with clinically used DNA-damaging anti-cancer drugs.

Acknowledgements The authors thank Dr. R. Uchida, Mr. K. Hagimori, Mr. H. Yamazaki, and Ms. S. Yokota (Kitasato University). We also thank Dr. T. Kawabe (CanBas Co., Ltd., Shizuoka, Japan) for kindly providing the Jurkat cells. This work was supported by a Grant-in-Aid for Young Scientists (start-up) 20810028 (to D. M.) and Scientific Research (B) 18390008 (to H. T.) from the Ministry of Education, Culture, Sports, Science and Technology of Japan, and by Kitasato University Research Grant for Young Researchers (to D. M.).

\section{REFERENCES}

1) Hartwell LH, Kastan MB. Cell cycle control and cancer. Science, 
266, $1821-1828$ (1994).

2) Levine AJ. p53, the cellular gatekeeper for growth and division. Cell, 88, 323-331 (1997).

3) Suganuma M, Kawabe T, Hori H, Funabiki T, Okamoto T. Sensitization of cancer cells to DNA damage-induced cell death by specific cell cycle G2 checkpoint abrogation. Cancer Res., 59, 5887-5891 (1999).

4) Cliby WA, Roberts CJ, Cimprich KA, Stringer CM, Lamb JR, Schreiber SL, Friend SH. Overexpression of a kinase-inactive ATR protein causes sensitivity to DNA-damaging agents and defects in cell cycle checkpoints. EMBO J., 17, 159-169 (1998).

5) Matsuoka S, Huang M, Elledge SJ. Linkage of ATM to cell cycle regulation by the Chk2 protein kinase. Science, 282, 1893-1897 (1998).

6) Sanchez Y, Wong C, Thoma RS, Richman R, Wu Z, PiwnicaWorms H, Elledge SJ. Conservation of the Chk1 checkpoint pathway in mammals: linkage of DNA damage to $\mathrm{Cdk}$ regulation through Cdc25. Science, 277, 1497-1501 (1997).

7) Harper JW, Elledge SJ. The DNA damage response: ten years after. Mol. Cell, 28, 739-745 (2007).

8) Blasina A, de Weyer IV, Laus MC, Luyten WH, Parker AE, McGowan CH. A human homologue of the checkpoint kinase Cds1 directly inhibits Cdc25 phosphatase. Curr. Biol., 9, 1-10 (1999).

9) O’Connell MJ, Raleigh JM, Verkade HM, Nurse P. Chk1 is a wee1 kinase in the G2 DNA damage checkpoint inhibiting cde2 by Y15 phosphorylation. EMBO J., 16, 545-554 (1997).

10) Raleigh JM, O'Connell MJ. The $\mathrm{G}_{2}$ DNA damage checkpoint targets both Weel and Cdc25. J. Cell Sci., 113, 1727-1736 (2000).

11) Bunch RT, Eastman A. Enhancement of cisplatin-induced cytotoxicity by 7-hydroxystaurosporine (UCN-01), a new G2-checkpoint inhibitor. Clin. Cancer Res., 2, $791-797$ (1996).

12) Fuse E, Tanii H, Kurata N, Kobayashi H, Shimada $Y$, Tamura $T$, Sasaki Y, Tanigawara Y, Lush RD, Headlee D, Figg WD, Arbuck SG, Senderowicz AM, Sausville EA, Akinaga S, Kuwabara T, Kobayashi S. Unpredicted clinical pharmacology of UCN-01 caused by specific binding to human alpha1-acid glycoprotein. Cancer Res., 58, 3248-3253 (1998).

13) Wang Q, Worland PJ, Clark JL, Carlson BA, Sausville EA. Apoptosis in 7-hydroxystaurosporine-treated $\mathrm{T}$ lymphoblasts correlates with activation of cyclin-dependent kinases 1 and 2. Cell Growth Differ., 6, 927-936 (1995).

14) Jackson JR, Gilmartin A, Imburgia C, Winkler JD, Marshall LA, Roshak A. An indolocarbazole inhibitor of human checkpoint kinase (Chk1) abrogates cell cycle arrest caused by DNA damage. Cancer Res., 60, 566-572 (2000)

15) Kohn EA, Yoo CJ, Eastman A. The protein kinase C inhibitor Gö6976 is a potent inhibitor of DNA damage-induced S and G2 cell cycle checkpoints. Cancer Res., 63, 31-35 (2003).

16) Sarkaria JN, Busby EC, Tibbetts RS, Roos P, Taya Y, Karnitz LM, Abraham RT. Inhibition of ATM and ATR kinase activities by the radiosensitizing agent, caffeine. Cancer Res., 59, 4375-4382 (1999).

17) Wang Y, Li J, Booher RN, Kraker A, Lawrence T, Leopold WR, Sun Y. Radiosensitization of p53 mutant cells by PD0166285, a novel $\mathrm{G}_{2}$ checkpoint abrogator. Cancer Res., 61, 8211-8217 (2001).

18) Sha SK, Sato T, Kobayashi H, Ishigaki M, Yamamoto S, Sato H, Takada A, Nakajyo S, Mochizuki Y, Friedman JM, Cheng FC, Okura T, Kimura R, Kufe DW, Vonhoff DD, Kawabe T. Cell cycle phenotype-based optimization of G2-abrogating peptides yields CBP501 with a unique mechanism of action at the G2 checkpoint. Mol. Cancer Ther., 6, 147-153 (2007).

19) Zabludoff SD, Deng C, Grondine MR, Sheehy AM, Ashwell S, Caleb BL, Green S, Haye HR, Horn CL, Janetka JW, Liu D, Mouchet E, Ready S, Rosenthal JL, Queva C, Schwartz GK, Taylor KJ, Tse AN, Walker GE, White AM. AZD7762, a novel checkpoint kinase inhibitor, drives checkpoint abrogation and potentiates DNAtargeted therapies. Mol. Cancer Ther., 7, 2955-2966 (2008).
20) Arai M, Sato H, Kobayashi H, Suganuma M, Kawabe T, Tomoda H, Omura S. Selective inhibition of bleomycin-induced G2 cell cycle checkpoint by simaomicin alpha. Biochem. Biophys. Res. Commun., 317, 817-822 (2004)

21) Arai M, Koizumi Y, Sato H, Kawabe T, Suganuma M, Kobayashi H, Tomoda H, Omura S. Boromycin abrogates bleomycin-induced G2 checkpoint. J. Antibiot., 57, 662-668 (2004).

22) Hagimori K, Fukuda T, Hasegawa Y, Omura S, Tomoda H. Fungal malformins inhibit bleomycin-induced G2 checkpoint in Jurkat cells. Biol. Pharm. Bull., 30, 1379-1383 (2007).

23) Pittayakhajonwut P, Theerasilp M, Kongsaeree P, Rungrod A, Tanticharoen M, Thebtaranonth Y. Pughiinin A, a sesquiterpene from the fungus Kionochaeta pughii BCC 3878. Planta Med., 68, $1017-1019$ (2002)

24) Harris GH, Hoogsteen K, Silverman KC, Raghoobar SL, Bills GF, Lingham RB, Smith JL, Dougherty HW, Cascales C, Peláez F. Isolation and structure determination of pycnidione, A novel bistropolone stromelysin inhibitor from a Phoma sp. Tetrahedron, 49, 2139-2144 (1993)

25) Wright AD, Lang-Unnasch N. Potential antimalarial lead structures from fungi of marine origin. Planta Med., 71, 964-966 (2005).

26) Yamori $\mathrm{T}$, Matsunaga A, Sato S, Yamazaki K, Komi A, Ishizu K, Mita I, Edatsugi H, Matsuba Y, Takezawa K, Nakanishi O, Kohno H, Nakajima Y, Komatsu H, Andoh T, Tsuruo T. Potent antitumor activity of MS-247, a novel DNA minor groove binder, evaluated by an in vitro and in vivo human cancer cell line panel. Cancer Res. 59, 4042-4049 (1999)

27) Matsuda D, Nakayama $Y$, Horimoto S, Kuga T, Ikeda K, Kasahara $\mathrm{K}$, Yamaguchi N. Involvement of Golgi-associated Lyn tyrosine kinase in the translocation of annexin II to the endoplasmic reticulum under oxidative stress. Exp. Cell Res., 312, 1205-1217 (2006).

28) Malumbres M, Barbacid M. Mammalian cyclin-dependent kinases. Trends Biochem. Sci., 30, 630-641 (2005).

29) Burgess A, Wigan M, Giles N, Depinto W, Gillespie P, Stevens F, Gabrielli B. Inhibition of S/G2 phase CDK4 reduces mitotic fidelity. J. Biol. Chem., 281, 9987-9995 (2006)

30) Palombella VJ, Rando OJ, Goldberg AL, Maniatis T. The ubiquitinproteasome pathway is required for processing the NF-kappa B1 precursor protein and the activation of NF-kappa B. Cell, 78 , 773 - 785 (1994).

31) Cutts SM, Rephaeli A, Nudelman A, Hmelnitsky I, Phillips DR. Molecular basis for the synergistic interaction of adriamycin with the formaldehyde-releasing prodrug pivaloyloxymethyl butyrate (AN-9). Cancer Res., 61, 8194-8202 (2001).

32) Sun Y, Xu Y, Roy K, Price BD. DNA damage-induced acetylation of lysine 3016 of ATM activates ATM kinase activity. Mol. Cell. Biol., 27, 8502-8509 (2007).

33) Rao VA, Agama K, Holbeck S, Pommier Y. Batracylin (NSC 320846), a dual inhibitor of DNA topoisomerases I and II induces histone gamma-H2AX as a biomarker of DNA damage. Cancer Res., 67, 9971-9979 (2007)

34) Renault G, Malvy C, Venegas W, Larsen AK. In vivo exposure to four ellipticine derivatives with topoisomerase inhibitory activity results in chromosome clumping and sister chromatid exchange in murine bone marrow cells. Toxicol. Appl. Pharmacol., 89, 281-286 (1987).

35) Kubota T, Fujita S, Kodaira S, Yamamoto T, Josui K, Arisawa Y, Suto A, Ishibiki K, Abe O, Mabuchi K, Fuse M. Antitumor activity of fluoropyrimidines and thymidylate synthetase inhibition. Jpn. J. Cancer Res., 82, 476-482 (1991).

36) Bagli JF, Bogri T, Palameta B, Martel R, Robinson W, Pugsley T, Lippmann W. Troponoids. 3. Synthesis and antiallergy activity of $N$-troponyloxamic acid esters. J. Med. Chem., 22, 1186-1193 (1979).

37) Roca J. Topoisomerase II: a fitted mechanism for the chromatin landscape. Nucleic Acids Res., 37, 721-730 (2009).

38) Etiévant C, Kruczynski A, Barret JM, Perrin D, Hill BT. Apoptotic 
cell death induction by F 11782 a novel dual catalytic inhibitor of topoisomerases I and II. Biochem. Pharmacol., 65, 755-763 (2003).

39) Feng JM, Zhu H, Zhang XW, Ding J, Miao ZH. Proteasome-dependent degradation of Chk1 kinase induced by the topoisomerase II inhibitor R16 contributes to its anticancer activity. Cancer Biol. Ther., 7, 1726-1731 (2008).

40) Zhu H, Miao ZH, Huang M, Feng JM, Zhang ZX, Lu JJ, Cai YJ, Tong LJ, Xu YF, Qian XH, Ding J. Naphthalimides induce $\mathrm{G}_{2}$ arrest through the ATM-Activated Chk2-executed pathway in HCT116 cells. Neoplasia, 11, 1226-1234 (2009).

41) Zhang YW, Otterness DM, Chiang GG, Xie W, Liu YC, Mercurio F, Abraham RT. Genotoxic stress targets human Chk1 for degradation by the ubiquitin-proteasome pathway. Mol. Cell, 19, 607-618 (2005).

42) Denny WA. Dual topoisomerase I/II poisons as anticancer drugs. Expert Opin. Investig. Drugs, 6, 1845-1851 (1997).

43) Mizuarai S, Yamanaka K, Itadani $\mathrm{H}$, Arai $\mathrm{T}$, Nishibata $\mathrm{T}$, Hirai $\mathrm{H}$, Kotani H. Discovery of gene expression-based pharmacodynamic biomarker for a p53 context-specific anti-tumor drug Weel inhibitor. Mol. Cancer, 8, 34 (2009).

44) Wagner MW, Li LS, Morales JC, Galindo CL, Garner HR, Bornmann WG, Boothman DA. Role of c-Abl kinase in DNA mismatch repair-dependent G2 cell cycle checkpoint arrest responses. J. Biol. Chem., 283, 21382-21393 (2008).

45) Sturgeon CM, Cinel B, Díaz-Marrero AR, McHardy LM, Ngo M, Andersen RJ, Roberge M. Abrogation of ionizing radiation-induced G2 checkpoint and inhibition of nuclear export by Cryptocarya pyrones. Cancer Chemother. Pharmacol., 61, 407-413 (2008).

46) Roberge M, Berlinck RG, Xu L, Anderson HJ, Lim LY, Curman D, Stringer CM, Friend SH, Davies P, Vincent I, Haggarty SJ, Kelly MT, Britton R, Piers E, Andersen RJ. High-throughput assay for G2 checkpoint inhibitors and identification of the structurally novel compound isogranulatimide. Cancer Res., 58, 5701-5706 (1998).

47) Curman D, Cinel B, Williams DE, Rundle N, Block WD, Goodarzi AA, Hutchins JR, Clarke PR, Zhou BB, Lees-Miller SP, Andersen RJ, Roberge M. Inhibition of the G2 DNA damage checkpoint and of protein kinases Chk1 and Chk2 by the marine sponge alkaloid debromohymenialdisine. J. Biol. Chem., 276, 17914-17919 (2001).

48) Song SY, Meszoely IM, Coffey RJ, Pietenpol JA, Leach SD. K-Rasindependent effects of the farnesyl transferase inhibitor L-744,832 on cyclin $\mathrm{B} 1 / \mathrm{Cdc} 2$ kinase activity, G2/M cell cycle progression and apoptosis in human pancreatic ductal adenocarcinoma cells. Neoplasia, 2, 261-272 (2000). 